\title{
Pengembangan Bahan Ajar Menulis Cerita Pendek dengan Pendekatan Kontekstual Berbasis Kearifan Lokal pada Siswa Kelas XI SMK
}

\author{
The Development of Teaching Materials to Write Short Stories with Contextual \\ Approach Based Local Wisdom for Class XI Students Vocational School
}

\author{
Arif Mazhuri Saputro ${ }^{1, *}$, M. Bahri Arifin ${ }^{2}$, Asnan Hefni $^{3}$ \\ ${ }^{1}$ Magister Pendidikan Bahasa dan Sastra Indonesia, FKIP, Universitas Mulawarman \\ ${ }^{2}$ FIB Universitas Mulawarman \\ ${ }^{3}$ FKIP Universitas Mulawarman \\ ${ }^{1}$ Corresponding email: arifmazhurisaputro@gmail.com \\ ${ }^{2}$ Email: mbahriarifin12@gmail.com \\ ${ }^{3}$ Email: asnan@fkip.unmul.ac.id
}

Received: 2 June 2020 Accepted: 9 January 2021 Published: 1 June 2021

\begin{abstract}
This research aims to produce teaching materials, describing the feasibility and effectiveness of teaching materials writing short stories with a contextual approach based on local wisdom in XI grade students of SMK Negeri 1 Kota Bangun. This research is a model of research and development. The data sources in this study are obtained from the development, implementation of learning, quality of products of development results, material development process, and material preparation. Data analysis techniques include measuring student writing test results, student response measurement, validation and planning assessment. This research resulted in teaching materials to write short stories with a contextual approach based on local wisdom for vocational class XI students. The feasibility of teaching materials is obtained from validation results by language experts (93.75\%). The media experts (88\%) category is very feasible with ready-to-use product decisions in the field without revision. The effectiveness of teaching materials can be seen from the results of the observer assessment, which is 3.65 classified very well. Furthermore, the teacher response calculation was $96.73 \%$, and the student response was obtained at $88.94 \%$, classified as very feasible with ready-to-use product decisions in the field without revision. The short story writing test results yielded an average score of $85.9 \%$, included in the excellent category. Test results write short stories on background aspects (100\%), themes (97.5\%) and language usage (90.83\%) fall into the category very well. Thus, teaching books writing short stories with a contextual approach based on local wisdom can be used in the learning process for vocational students in XI grade.
\end{abstract}

Keywords: teaching materials, writing short stories, approach to contextual, local wisdom.

\begin{abstract}
Abstrak: Penelitian ini bertujuan untuk menghasilkan bahan ajar, mendeskripsikan kelayakan dan efektivitas bahan ajar menulis cerpen dengan pendekatan kontekstual berbasis kearifan lokal pada siswa kelas XI SMK Negeri 1 Kota Bangun. Penelitian ini merupakan model penelitian dan pengembangan (R\&D). Sumber data dalam penelitian ini diperoleh dari desain pengembangan, pelaksanaan pembelajaran, kualitas produk hasil pengembangan, proses pengembangan materi, dan penyusunan materi. Teknik analisis data meliputi pengukuran hasil tes menulis siswa, pengukuran respons siswa, validasi dan penilaian perencanaan. Penelitian ini menghasilkan bahan ajar menulis cerpen dengan pendekatan kontekstual berbasis kearifan lokal untuk siswa kelas XI SMK. Kelayakan bahan ajar diperoleh dari hasil validasi oleh ahli materi dan bahasa (93,75\%) dan ahli media (88\%) terkategori sangat layak dengan keputusan produk siap dipakai di lapangan tanpa revisi. Tingkat efektivitas bahan ajar dapat dilihat dari hasil penilaian observer, yaitu 3,65 terkategori sangat baik. Selanjutnya hasil perhitungan respons guru sebesar $96,73 \%$ dan respons siswa diperoleh $88,94 \%$ terkategori sangat layak dengan keputusan produk siap dipakai di lapangan tanpa revisi. Hasil tes menulis cerpen menghasilkan nilai ratarata $85,9 \%$ termasuk dalam kategori sangat baik. Hasil tes menulis cerpen pada aspek latar $(100 \%)$, tema $(97,5 \%)$ dan penggunaan bahasa (90,83\%) termasuk dalam kategori sangat baik. Dengan demikian produk buku ajar menulis cerpen dengan pendekatan kontekstual berbasis kearifan lokal dapat digunakan dalam proses pembelajaran untuk siswa kelas XI SMK.
\end{abstract}

Kata kunci: bahan ajar, kearifan lokal, menulis cerpen, pendekatan kontekstual. 
To cite this article:

Saputro, A. M., Arifin, M. B., \& Hefni, A. (2021). Pengembangan Bahan Ajar Menulis Cerita Pendek dengan Pendekatan Kontekstual Berbasis Kearifan Lokal pada Siswa Kelas XI SMK. Diglosia: Jurnal Kajian Bahasa, Sastra, dan Pengajarannya, 4(2), 235-246. https://doi.org/10.30872/diglosia.v4i2.98

\section{A. PENDAHULUAN}

Dunia perkembangan pendidikan di Indonesia berkembang dengan pesat sehingga memacu para peneliti untuk menyempurnakan kurikulum yang berlaku. Adanya pemberlakuan Kurikulum Tingkat Satuan Pendidikan (KTSP) yang disempurnakan dalam bentuk Kurikulum 2013 merupakan langkah pengembangan Kurikulum Berbasis Kompetensi (KBK) yang dirintis pada tahun 2004 dan KTSP 2006 mencakup kompetensi sikap, pengetahuan, dan keterampilan secara terpadu.

Bahan ajar sangat berpengaruh dalam kesuksesan proses pembelajaran di dalam kelas selain faktor seorang guru. Bahan ajar juga dituntut dapat mendukung terselenggaranya proses pembelajaran yang baik Majid (2007, p. 173) menyatakan bahwa bahan ajar merupakan segala bentuk bahan yang digunakan untuk membantu guru dalam melaksanakan kegiatan belajar mengajar. Tersedianya bahan ajar memungkinkan peserta didik untuk mempelajari suatu kompetensi secara sistematis sehingga mampu menguasai kompetensi secara utuh dan terpadu. Oleh sebab itu, guru harus mampu memilih bahan ajar yang tepat sehingga peserta didik bisa mencapai kompetensi yang diinginkan secara maksimal (Wijayanti, Zulaeha, \& Rustono, 2015). Bahan ajar adalah segala bahan baik informasi, alat, maupun teks yang disusun secara sistematis, menampilkan kompetensi yang akan dikuasai peserta didik dan digunakan dalam proses pembelajaran dengan tujuan perencanaan serta penelaahan implementasi pembelajaran (Prastowo, 2013).

Setiap kebudayaan di Indonesia memiliki nilai luhur yang tetap dipertahankan. Nilai tersebut dapat dikatakan sebagai kearifan lokal (local knowladge, local wisdom) yang dapat dimanfaatkan untuk pendidikan nilai dengan pendekatan yang berbeda. Di antara kita selama ini silau dengan sistem pendidikan Barat sehingga buta terhadap kearifan lokal yang lama terpendam dalam bumi kebudayaan Indonesia. Oleh karena itu, perlu dirumuskan pendekatan pendidikan berbasis kearifan budaya lokal bagi masyarakat Indonesia yang majemuk (Ramdani, 2018).

Menulis adalah salah satu kemampuan berbahasa yang bersifat produktif karena menghasilkan suatu produk, yaitu tulisan. Menurut Murray \& Moore (2009) dan Padmi (2017), menulis adalah suatu proses dan kegiatan yang kompleks serta kreatif. Seseorang perlu mempelajari bagaimana merangkai atau memilih kata yang memiliki keberterimaan dengan konteks dan menyusunnya ke dalam sebuah kalimat atau paragraf dengan bahasa yang mudah dicerna oleh pembaca. Dengan kreativitasnya, penulis mempengaruhi emosi pembacanya agar larut dalam kisah yang ditulisnya (Harefa, 2007). Sejalan dengan hal tersebut, Aksan (2011) menjelaskan bahwa menulis dapat meningkatkan kecerdasan linguistik seseorang. Seseorang yang memiliki inteligensi linguistik akan mampu menggunakan dan mengolah kata-kata secara efektif. Adapun pembelajaran menulis cerita pendek (cerpen) terdapat pada Silabus kelas XI di Sekolah Menengah Kejuruan (SMK) pada Kompetensi Dasar (KD) 4.9, yaitu merekonstruksi sebuah cerita pendek dengan memperhatikan unsur-unsur pembangun cerpen (Padmi, 2017). 
Pembelajaran menulis cerpen di sekolah lebih fokus pada teori daripada mengakrabkan siswa dengan karya sastra secara langsung. Sifat pembelajaran teoretis membuat para siswa mengalami hambatan dalam menuangkan ide cerpen dengan baik dan sistematis. Pada dasarnya dalam pembelajaran menulis cerpen siswa diajak untuk berpikir kritis, kreatif, dan sistematis. Namun hal ini sukar untuk direalisasikan di kelas, terutama pada saat KBM. Selama ini pendekatan pembelajaran yang digunakan adalah teacher centered dengan metode ceramah. Pembelajaran yang bersifat monoton tersebut menyebabkan siswa jenuh sehingga pembelajaran menulis cerpen dirasa kurang menarik (Padmi, 2017).

Pendekatan kontekstual (Contextual Teaching and Learning/CTL) adalah konsep belajar yang membawa dunia nyata ke dalam kelas dan mendorong siswa untuk mengimplementasikan pengetahuan yang dimiliki ke dalam ruang lingkup masyarakat. Dalam pendekatan kontekstual terdapat tujuh komponen utama, meliputi konstruktivisme (constructivism), bertanya (questioning), menemukan (inquiri), masyarakat belajar (learning community), pemodelan (modeling), dan penilaian (authentic assessment) (Umami, 2018).

Pembelajaran melalui pendekatan kontekstual menekankan pembelajaran berbasis masalah. Selain itu, guru harus memahami keadaan belajar siswa dari sudut pandang pengetahuan atau latar belakang kehidupan sosial budayanya. Materi pembelajaran yang disediakan harus bersifat kontekstual, artinya menyentuh nilainilai kehidupan nyata yang terjadi di sekitar lingkungan siswa. Hal tersebut membuat peserta didik belajar mandiri baik secara pribadi maupun kelompok peran guru hanya sebagai fasilitator (Padmi, 2017).

Pada dasarnya pendidikan berkualitas adalah pendidikan yang mampu mengangkat nilai kearifan lokal dan membantu siswa mengembangkan diri guna memperkuat jati diri kebangsaan yang telah dimiliki. Hal ini sejalan dengan pendapat Tilaar yang menyatakan bahwa kearifan lokal dalam perspektif pendidikan menjadi modal dasar bagi proses pertumbuhan pendidikan. Senada dengan pendapat tersebut, Utari mengemukakan bahwa untuk mengontekstualkan pembelajaran melalui penanaman nilai kearifan lokal sehingga siswa secara tidak langsung dilatih untuk lebih peka terhadap sekitarnya (Wafiqni \& Nurani, 2019).

Menurut Devi \& Hidayati (2016) pendekatan pembelajaran yang digunakan berbasis kearifan lokal salah satunya, yaitu pendekatan pembelajaran kontekstual. Pendekatan ini dapat menunjang pembelajaran berbasis kearifan lokal yang merupakan bagian dari pengenalan nilai dan norma masyarakat sekitar dalam kehidupan nyata dan mudah diterima oleh siswa. Penggunaan pendekatan kontekstual guna pengembangan pembelajaran berbasis kearifan lokal memiliki hubungan, yaitu pada pembelajaran dengan kehidupan nyata sedangkan untuk mengembangkan pembelajaran berbasis kearifan lokal juga dari kehidupan nyata siswa.

Tujuan penelitian ini adalah (1) menghasilkan bahan ajar menulis cerita pendek dengan pendekatan kontekstual berbasis kearifan lokal pada siswa kelas XI SMK Negeri 1 Kota Bangun sesuai dengan proses pengembangan bahan ajar yang baik; (2) mendeskripsikan kelayakan bahan ajar menulis cerita pendek dengan pendekatan kontekstual berbasis kearifan lokal pada siswa kelas XI SMK Negeri 1 Kota Bangun; serta (3) mendeskripsikan efektivitas bahan ajar menulis cerita pendek dengan pendekatan kontekstual berbasis kearifan lokal pada siswa kelas XI SMK Negeri 1 Kota Bangun. Adanya buku ajar ini diharapkan dapat membantu siswa dalam 
pembelajaran menulis cerpen. Selain itu, dapat memberikan referensi bagi guru dalam menentukan bahan ajar di samping buku teks yang tersedia. Bahan ajar ini bagi guru sebagai alternatif bahan ajar untuk pembelajaran dan penguasaan materi cerita pendek serta mempermudah penyampaian materi cerita pendek karena buku ini lebih fokus pada satu keterampilan saja.

\section{B. METODE}

Penelitian ini merupakan model penelitian dan pengembangan atau dikenal dengan istilah Research \& Development (R\&D). Metode penelitian dan pengembangan adalah metode yang digunakan untuk menghasilkan produk tertentu dan menguji keefektifan produk tersebut (Sugiyono, 2016). Prosedur pengembangan bahan ajar menulis cerpen dengan pendekatan kontekstual berbasis kearifan lokal terdiri atas sepuluh langkah, yaitu: (1) potensi dan masalah, (2) pengumpulan informasi, (3) desain produk, (4) validasi desain, (5) perbaikan desain, (6) uji coba produk, (7) revisi produk, (8) uji coba pemakaian, (9) revisi produk, dan (10) pembuatan produk masal (Gall, Gall, \& Borg, 2003; Nurhana, Siddik, \& Ridhani, 2020).

Penelitian ini dilaksanakan di SMK Negeri 1 Kota Bangun kelas XI. Sumber data dalam penelitian ini diperoleh dari desain pengembangan, pelaksanaan pembelajaran, kualitas produk hasil pengembangan, proses pengembangan materi, dan penyusunan materi. Instrumen penelitian dalam kegiatan pengumpulan informasi menggunakan lembar observasi, angket, lembar validasi dan dokumentasi (Rajja, Arifin, \& Mursalim, 2020). Teknik analisis data dalam penelitian ini terdiri dari mengukur hasil tes menulis cerpen siswa, pengukuran respons siswa terhadap bahan ajar, validasi bahan ajar oleh validator ahli materi juga bahasa dan ahli media, serta penilaian perencanaan menggunakan kriteria pengembangan bahan ajar oleh Purwanto (2010).

\section{PEMBAHASAN}

1. Proses Pengembangan Bahan Ajar Menulis Cerpen dengan Pendekatan Kontekstual Berbasis Kearifan Lokal Pada Siswa Kelas XI SMK

Proses pengembangan bahan ajar terdiri dari sepuluh langkah, yaitu potensi dan masalah, pengumpulan informasi, desain produk, validasi desain, perbaikan desain, uji coba produk, revisi produk, uji coba pemakaian, revisi produk, dan pembuatan produk masal. Dalam penelitian ini peneliti mengembangkan pembelajaran menulis cerpen menggunakan pendekatan kontekstual berbasis kearifan lokal.

Pada langkah awal peneliti telah melakukan tahap I, yaitu mengidentifikasi potensi dan masalah melalui pengamatan langsung di dalam kelas dengan tujuan observasi lapangan dan studi pendahuluan yang terdiri dari wawancara tidak terstruktur kepada guru serta siswa untuk mengetahui informasi mengenai kurikulum yang digunakan, ketersediaan sumber belajar, juga karakteristik siswa di SMK Negeri 1 Kota Bangun.

Selanjutnya dilakukan tahap II, yaitu pelaksanaan pengembangan bahan ajar yang terdiri dari mendesain materi yang dikembangkan kemudian di validasi oleh ahli materi juga bahasa dan ahli media. pada tahap validasi bahan ajar menulis cerpen dengan pendekatan kontekstual berbasis kearifan lokal untuk siswa SMK kelas XI yang dilakukan oleh ahli menghasilkan data kuantitatif dan kualitatif yang dijadikan acuan untuk melakukan revisi. Setelah dilakukan revisi sesuai saran dari validator kemudian melakukan uji coba produk pada kelompok kecil untuk 
memperoleh masukan langsung berupa respons siswa dan guru terhadap bahan ajar menulis cerpen dengan pendekatan kontekstual berbasis kearifan lokal untuk siswa SMK kelas XI.

Tahap III dilakukan uji coba produk bahan ajar menulis cerpen dengan pendekatan kontekstual berbasis kearifan lokal untuk siswa SMK kelas XI dalam kelompok besar. Pada tahap ini, penulis juga membagikan angket kepada guru dan siswa untuk mengetahui respons terhadap bahan ajar serta observer untuk menilai pelaksanaan pembelajaran menulis cerpen dengan pendekatan kontekstual berbasis kearifan lokal untuk siswa kelas XI. Setelah dilakukan uji coba produk dalam kelompok besar, penulis melakukan revisi produk bahan ajar sesuai dengan hasil angket respons guru dan siswa serta penilaian dari observer untuk menyempurnakan produk yang telah dikembangkan. Langkah terakhir dari tahap ini adalah produksi massal bahan ajar yang telah teruji untuk dimanfaatkan oleh orang lain. Dapat disimpulkan bahwa proses pengembangan bahan ajar menulis cerita pendek dengan pendekatan kontekstual berbasis kearifan lokal terlaksana dengan baik sesuai struktur dari Borg \& Gall (Gall et al., 2003; Sugiyono, 2016).

\section{a. Penulisan Bahan ajar}

Proses penulisan bahan ajar menulis cerpen dengan pendekatan kontekstual berbasis kearifan lokal oleh peneliti dan penulisan cerpen yang dilakukan siswa sesuai dengan tahapan penulisan menurut Dalman (2018, pp. 15-19) sebagai berikut.

\section{1) Tahap Prapenulisan}

a) Penentuan topik dengan cara melakukan studi pendahuluan menggunakan teknik wawancara tidak terstruktur terkait informasi mengenai kurikulum yang digunakan, ketersediaan sumber belajar meliputi ketersediaan buku. Pada tahap ini peneliti berupaya mencari informasi apakah pelaksanaan pengembangan pembelajaran pada materi menulis cerpen tepat dilaksanakan di SMK Negeri 1 Kota Bangun. Pada tahap penentuan topik ini siswa di rangsang oleh guru untuk mengingat kembali hal-hal yang terjadi di sekitar lingkungan tempat tinggal mereka. Hal ini dilakukan untuk mempermudah siswa mencari topik berbasis kearifan lokal yang nantinya akan dituangkan dalam alur cerpen.

b) Maksud dan tujuan penulisan buku ajar ini agar peserta didik mampu menentukan unsur-unsur pembangun cerita pendek yang disajikan, menelaah teks cerita pendek yang disajikan berdasarkan struktur kaidah, menentukan topik tentang kehidupan dalam cerita pendek yang disajikan dan menulis cerita pendek yang disajikan dengan memperhatikan unsur-unsur pembangun. Maksud dan tujuan penugasan cerpen ini adalah mengasah keterampilan menulis siswa dengan topik lingkungan sekitar tempat tinggal serta kebudayaan yang hadir dalam ruang lingkup keseharian siswa.

c) Sasaran karangan (pembaca) dalam penelitian ini adalah siswa SMK kelas XI. Setelah dilakukan perbaikan desain bahan ajar dengan mengacu pada saran dari ahli media, maka buku ajar dengan penggunaan pendekatan kontekstual tersaji dengan baik, hal itu dapat dilihat pada hasil produk Buku Ajar Menulis Cerpen dengan Pendekatan Kontekstual Berbasis Kearifan Lokal Pada Siswa Kelas XI SMK Negeri 1 Kota Bangun. Pada tahap ini siswa menulis cerpen kearifan lokal dengan sasaran karangan untuk di pamerkan dalam majalah dinding sekolah selain sebagai tugas penutup materi cerpen.

d) Pengumpulan informasi pendukung di antaranya dengan melihat karakteristik siswa dari segi latar belakang pengetahuan siswa, sikap terhadap materi 
pembelajaran, bahasa yang digunakan, usia, dan kemampuan bekerja sama. Sedangkan analisis kemampuan akademik siswa dapat diperoleh melalui wawancara langsung kepada guru mata pelajaran Bahasa Indonesia dan dilihat hasil belajar pada semester sebelumnya yang digunakan sebagai dasar untuk melaksanakan pengembangan pembelajaran. Pada tahap pengumpulan informasi untuk menulis cerpen para siswa memanfaatkan perpustakaan, media daring, dan memori untuk melengkapi gagasan yang telah tertulis dalam cerpen. Latar belakang sosial budaya siswa yang berbeda-beda sangat dimanfaatkan untuk bertukar cerita mengenai lingkungan sekitar tempat tinggal siswa.

e) Setelah mempertimbangkan kemampuan pembaca maka langkah selanjutnya adalah mengorganisasikan atau menata ide-ide karangan agar saling bertaut dan padu. Penulis menyusun kerangka karangan sehingga buku ajar dapat tersusun secara sistematis. Pada tahap ini siswa membuat susunan ide pokok untuk masing-masing paragraf sesuai tema yang akan ditulis dalam cerpen dan dibimbing oleh guru.

\section{2) Tahap Penulisan}

Pada tahap ini penulis mengembangkan butir demi butir ide yang terdapat dalam kerangka karangan dengan memanfaatkan bahan atau informasi yang telah dipilih dan dikumpulkan. Struktur karangan terdiri atas bagian awal, isi, dan akhir. Buku ajar yang disajikan dalam penelitian ini terdiri dari buku ajar untuk guru dan buku ajar untuk siswa. Adapun kerangka karangan pada bagian awal dalam buku ajar untuk guru, meliputi sampul, kata pengantar, daftar isi, kompetensi dasar pembelajaran cerpen, tujuan pembelajaran, langkah-langkah menggunakan bahan ajar (kegiatan belajar 1 dan kegiatan belajar 2, pengenalan cerpen disertai contoh cerpen. Pada bagian isi meliputi pengertian cerpen, karakteristik cerpen, struktur cerpen, unsur pembangun cerpen, kaidah kebahasaan cerpen, jenis gaya bahasa yang digunakan dalam cerpen, berlatih menulis cerpen dengan pendekatan kontekstual berbasis kearifan lokal, dan rangkuman. Kemudian pada bagian akhir meliputi tugas kelompok, tugas mandiri dilengkapi dengan kunci jawaban, daftar pustaka dan Rencana Pelaksanaan Pembelajaran (RPP) Kompetensi Dasar 4.9, yaitu merekonstruksi sebuah cerita pendek dengan memerhatikan unsur-unsur pembangun cerpen.

Sedangkan kerangka karangan pada bagian awal dalam buku ajar untuk siswa, meliputi sampul, daftar isi, kompetensi dasar pembelajaran cerpen, tujuan pembelajaran, pengenalan cerpen disertai contoh cerpen. Pada bagian isi meliputi pengertian cerpen, karakteristik cerpen, struktur cerpen, unsur pembangun cerpen, kaidah kebahasaan cerpen, jenis gaya bahasa yang digunakan dalam cerpen, dan rangkuman. Kemudian pada bagian akhir meliputi tugas kelompok, tugas mandiri, dan daftar pustaka.

Pada tahap penulisan cerpen, siswa memanfaatkan kerangka karangan yang telah dibuat. Ide-ide pokok yang telah tertuang dalam kerangka karangan kemudian dikembangkan sesuai tema dan alur yang telah dipilih sebelumnya.

\section{3) Tahap Pascapenulisan}

Pada tahap ini dilakukan kegiatan penyuntingan dan perbaikan (revisi) oleh ahli materi juga bahasa dan ahli media. Validator membaca keseluruhan karangan dan menandai hal-hal yang perlu diperbaiki atau yang harus diganti, ditambahkan, dan 
disempurnakan. Selanjutnya, penulis melakukan perbaikan sesuai dengan temuan saat penyulingan, setelah tuntas maka buku ajar dapat dicetak.

\section{b. Pendekatan Kontekstual}

Pendekatan kontekstual yang digunakan oleh peneliti dalam buku ajar merujuk pada Sanjaya (2012, p. 264) dapat diuraikan sebagai berikut.

\section{1) Konstruktivisme (Contructivisme)}

Pada tahap ini guru harus memotivasi dan mendorong siswa dapat mengonstruksi pengetahuannya melalui proses pengamatan dan pengalaman. Siswa didorong untuk mampu mengonstruksi pengetahuan sendiri melalui pengalaman nyata dalam kehidupannya sehari-hari yang berbasis kearifan lokal. Pada tahap ini guru harus memicu ingatan siswa untuk fokus pada kebiasaan sehari-hari dan budaya sebagai bahan cerpen.

\section{2) Menemukan (Inquiry)}

Yamin (2013, p. 56) menjelaskan bahwa inkuiri berarti proses pembelajaran didasarkan pada pencarian dan penelusuran melalui proses berpikir secara sistematis. Pengetahuan yang dipelajari menjadi milik siswa sendiri ketika pengetahuan itu dipelajari dalam kerangka konteks kehidupan nyata.

\section{3) Bertanya (Questioning)}

Peran bertanya sangat penting, sebab melalui pertanyaan-pertanyaan guru dapat membimbing dan mengarahkan siswa untuk menemukan setiap materi yang dipelajarinya. Guru harus berperan aktif melempar pertanyaan kepada siswa dan mengalihkan jawaban pada siswa lain.

\section{4) Masyarakat Belajar (Learning Community)}

Pada tahap ini guru harus memperhatikan bahwa hasil pembelajaran diperoleh melalui kerja sama dengan orang lain. Dalam pendekatan kontekstual, penerapan asas masyarakat belajar dapat dilakukan dengan menerapkan pembelajaran melalui kelompok belajar. Siswa yang memiliki kemampuan lebih akan membantu siswa lain yang kemampuannya kurang.

\section{5) Pemodelan (Modelling)}

Pada tahap ini guru memberikan contoh bagaimana menulis cerpen berbasis kearifan lokal karya Syafruddin Pernyata yang berjudul Surat Ayah dari Rantau. Dalam cerpen tersebut menggambarkan kehidupan di sekitar penulis. Proses modeling tidak terbatas dari guru saja, akan tetapi dapat juga guru memanfaatkan siswa yang dianggap memiliki kemampuan.

\section{6) Refleksi (Reflection)}

Pada tahap ini guru memberikan kesempatan kepada siswa untuk "merenung" atau mengingat kembali apa yang telah dipelajarinya. Biarkan secara bebas siswa menafsirkan pengalamannya sendiri sehingga ia dapat menyimpulkan tentang pengalaman belajarnya. 


\section{7) Penilaian nyata (Authentic assessment)}

Penilaian ini dilakukan secara terus-menerus selama kegiatan pembelajaran berlangsung. Dalam melakukan penilaian guru juga harus memiliki wawasan mengenai kearifan lokal di sekitar dengan tujuan mengurangi subjektifitas penilaian.

Buku ajar memuat contoh cerpen Surat Ayah dari Rantau oleh Syafruddin Pernyata yang merupakan seorang penulis asal Kalimantan Timur. Pada pembelajaran menulis cerpen, siswa diajak untuk berpikir kritis, kreatif, dan sistematis. Dalam penelitian pendekatan kontekstual berbasi kearifan lokal ini bukan berfokus pada satu ciri khas utama dari suatu daerah sehingga menyababkan teacher centered. Dengan menggunakan buku ajar ini guru dapat menerapkan metode pembelajaran student centered, yaitu metode yang berfokus pada siswa sehingga guru hanya menjadi fasilitator saja sehingga pendekatan kontekstual berbasis kearifan lokal yang menyajikan materi dari lingkungan sekitar serta kehidupan nyata siswa dapat diimplementasikan.

Perspektif penelitian bahan ajar berbasis kearifan lokal ini guru memberikan contoh bagaimana menulis cerpen berbasis kearifan lokal karya Syafruddin Pernyata yang berjudul Surat Ayah dari Rantau dalam cerpen tersebut menggambarkan kehidupan di sekitar penulis. Guru harus memicu ingatan siswa untuk fokus pada kebiasaan sehari-hari dan budaya sebagai bahan cerpen.

Siswa harus mengaitkan struktur dan unsur cerpen dengan peristiwa di sekitar lingkungan sekolah dan dalam kehidupan nyata. Seperti adanya contoh karya cerpen siswa dalam penelitian yang telah dilakukan pada siswa kelas XI di SMK Negeri 1 Kota Bangun yang berjudul Jembatan Mardipura. Jembatan ini menghubungkan Kecamatan Kota Bangun dengan lima Kecamatan lain yang sebelumnya terisolir, yaitu Tabang, Kembang Janggut, Kenohan, Muara Wis dan Muara Muntai. Jembatan ini juga merupakan jembatan terpanjang di Indonesia yang memiliki panjang 15,3 kilometer. Selanjutnya karya siswa yang berjudul Melestarikan Budaya Etam yang menceritakan tentang permainan tradisional anak-anak suku Kutai, yaitu begasing, betisan/egrang, bekiak, behampas bantal, betumbuk haur, dan nyumpit. Dari beberapa karya cerpen siswa di atas menggambarkan kearifan lokal yang berada di sekitar lingkungan tempat tinggalnya.

\section{Kelayakan Bahan Ajar Menulis Cerpen dengan Pendekatan Kontekstual Berbasis Kearifan Lokal Pada Siswa Kelas XI SMK \\ a. Analisis hasil validasi bahan ajar oleh ahli materi juga bahasa}

Berdasarkan hasil validasi oleh ahli materi juga bahasa terhadap bahan ajar yang meliputi aspek kelayakan isi, kelayakan penyajian, kelayakan bahasa menurut BSNP dan penilaian kontekstual diperoleh total skor 150, skor maksimal yang diharapkan berjumlah 160, maka diperoleh persentase sebesar 93,75\% dan kesimpulan dari ahli materi juga bahasa buku ajar dapat digunakan dengan revisi. Apabila dilihat dari tabel uji kelayakan produk dari Purwanto (2010), maka 93,75\% termasuk dalam persentase 86\%-100\%, kategori "Sangat Layak" dengan keputusan produk siap dipakai di lapangan tanpa revisi.

\section{b. Analisis hasil validasi bahan ajar oleh ahli media}


Menurut hasil validasi oleh ahli media terhadap bahan ajar terkait aspek kelayakan kegrafikan menurut BSNP terdiri dari ukuran buku ajar, desain sampul buku ajar, dan desain isi buku ajar maka diperoleh total skor 95, skor maksimal berjumlah 108, maka diperoleh persentase sebesar $88 \%$ dan kesimpulan dari ahli media buku ajar dapat digunakan dengan revisi. Apabila dilihat dari tabel uji kelayakan produk dari Purwanto (2010) maka 88\% termasuk dalam persentase $86 \%$ $100 \%$, kategori "Sangat Layak" dengan keputusan produk siap dipakai di lapangan tanpa revisi.

\section{Efektivitas Bahan Ajar Menulis Cerpen dengan Pendekatan Kontekstual Berbasis Kearifan Lokal Pada Siswa Kelas XI SMK}

Uji coba kelompok besar diwakili oleh 30 siswa terdiri dari 10 orang laki-laki dan 20 orang perempuan. Responden yang digunakan dalam kelompok besar sebanyak 30 siswa dipilih secara acak dari kelas XI-A dan XI-B.

a. Analisis Hasil Observasi Aktivitas Guru dan Siswa terhadap Bahan Ajar pada Kelompok Besar

Untuk mengetahui tingkat keefektifan bahan ajar menggunakan lembar observasi aktivitas guru dan siswa yang dilakukan selama proses pembelajaran berlangsung. Observer dalam penelitian ini adalah Bapak Hasanuddin, S.Pd selaku Wakil Kepala Sekolah bagian Kurikulum di SMK Negeri 1 Kota Bangun. Berdasarkan pada penilaian observer dapat diketahui bahwa lembar observasi aktivitas guru dan siswa menggunakan pendekatan kontekstual diperoleh nilai 3,65. Apabila dilihat dari tabel kriteria penilaian aktivitas guru dari Mulyana (2018) maka nilai 3,65 termasuk dalam rentang $3,51 \leq$ nilai $\leq 4,00$ sehingga termasuk dalam kategori "Sangat Baik".

\section{b. Analisis Hasil Respons Guru dan Siswa terhadap Bahan Ajar pada Kelompok Besar}

Untuk mengetahui tingkat keefektifan bahan ajar selain observasi yang dilakukan selama proses pembelajaran berlangsung juga melalui respons guru dan siswa terhadap bahan ajar. Berdasarkan hasil perhitungan diketahui bahwa respons guru terhadap bahan ajar dengan total skor 89 sehingga diperoleh persentase sebesar $96,73 \%$. Apabila dilihat dari tabel uji kelayakan produk dari Purwanto (2010) maka 96,73\% termasuk dalam persentase 86\%-100\%, kategori "Sangat Layak" dengan keputusan produk siap dipakai di lapangan tanpa revisi.

Sedangkan hasil perhitungan respons siswa terhadap bahan ajar pada kelompok besar dari 30 responden terdapat 18 responden yang memberikan penilaian dengan kategori sangat layak sedangkan 12 responden memberikan penilaian dengan kategori baik/layak. Apabila dilihat dari tabel uji kelayakan produk dari Purwanto (2010) maka rata-rata persentase adalah $88,94 \%$ termasuk dalam rentang persentase 86\%-100\%, kategori "Sangat Layak" dengan keputusan produk siap dipakai di lapangan tanpa revisi.

\section{c. Analisis Hasil Tes Menulis Cerpen pada Kelompok Besar}

Tes menulis cerpen pada kelompok besar diwakili oleh 30 siswa terdiri dari 10 orang laki-laki dan 20 orang perempuan. Responden yang digunakan dalam kelompok besar sebanyak 30 siswa dipilih secara acak dari kelas XI-A dan XI-B. Adapun hasil tes menulis cerpen pada kelompok besar adalah sebagai berikut. 
Tabel 1. Hasil Tes Menulis Cerpen Kelompok Besar

\begin{tabular}{clcccccc}
\hline No & Kategori & Rentang & F & Bobot & \% & $\begin{array}{c}\text { Nilai } \\
\text { Rata-Rata }\end{array}$ & Ketuntasan \\
\hline 1 & Sangat Baik & $85-100$ & 17 & 1492 & 56,66 & & \\
2 & Baik & $75-84$ & 13 & 1085 & 43,33 & & 85,9 \\
3 & Cukup & $60-74$ & 0 & 0 & 0 & 85,9 & (Sangat baik) \\
4 & Kurang Jumlah & $0-59$ & 0 & 0 & 0 & & \\
& & $\mathbf{3 0}$ & $\mathbf{2 5 7 7}$ & $\mathbf{1 0 0 \%}$ & & \\
\hline
\end{tabular}

Hasil tes menulis cerpen menunjukkan bahwa total skor pada kelompok besar adalah 2577 dengan rata-rata 85,9 termasuk dalam kategori sangat baik. Dari 30 siswa terdapat 56,66\% atau 17 siswa yang memiliki hasil tes menulis cerpen dengan kategori sangat baik dalam rentang 85-100. Kategori baik dengan rentang 75-84 terdapat $43,33 \%$ atau 13 siswa. Dengan demikian, dapat disimpulkan hasil tes menulis cerpen pada kelompok besar dalam kategori sangat baik.

Tabel 2. Hasil Tes Menulis Cerpen Kelompok Besar pada Tiap Aspek

\begin{tabular}{clcc}
\hline No & Aspek yang dinilai & Nilai Rata-Rata & Kategori \\
\hline 1 & Kesesuaian judul dengan isi & 82,5 & Baik \\
2 & Tema & 97,5 & Sangat baik \\
3 & Alur & 80,83 & Baik \\
4 & Latar & 100 & Sangat baik \\
5 & Tokoh dan penokohan & 75 & Baik \\
6 & Sudut pandang & 82,5 & Baik \\
7 & Gaya bahasa & 81,66 & Baik \\
8 & Penggunaan bahasa & 90,83 & Sangat baik \\
\hline
\end{tabular}

Selanjutnya dilihat dari hasil tes menulis cerpen tiap aspek dalam kelompok besar pada aspek latar (100\%), tema (97,5\%) dan penggunaan bahasa $(90,83 \%)$ termasuk dalam kategori sangat baik. Selanjutnya pada masing-masing aspek kesesuaian judul dengan isi, alur, tokoh dan penokohan, sudut pandang, serta gaya bahasa memiliki hasil tes menulis cerpen dengan kategori baik.

Data hasil uji coba bahan ajar di lapangan termasuk dalam kategori sangat layak/baik dan sangat efektif dengan keputusan produk siap dipakai di lapangan tanpa revisi.

\section{PENUTUP}

Berdasarkan hasil temuan dan pembahasan dapat disimpulkan beberapa hal sebagai berikut. Pertama, proses pengembangan bahan ajar menulis cerpen menggunakan pendekatan kontekstual berbasis kearifan lokal meliputi langkah awal peneliti telah melakukan tahap I studi pendahuluan yang terdiri dari wawancara tidak terstruktur kepada guru dan siswa untuk mengetahui kondisi di SMK Negeri 1 Kota Bangun. Selanjutnya dilakukan tahap II, yaitu tahap pelaksanaan pengembangan bahan ajar yang terdiri dari mendesain materi yang dikembangkan, data yang diperlukan adalah desain materi dan desain pengembangan bahan ajar. Tahap III dilakukan uji coba produk yang terdiri dari validasi desain oleh para ahli untuk menguji kelayakan produk dengan menggunakan lembar validasi, revisi desain, uji coba produk yang terdiri dari tulisan atau karangan siswa dan hasil belajarnya. Dapat disimpulkan bahwa proses pengembangan bahan ajar menulis 
cerita pendek dengan pendekatan kontekstual berbasis kearifan lokal terlaksana dengan baik.

Kedua, kelayakan bahan ajar diperoleh dari hasil validasi oleh ahli materi juga bahasa meliputi aspek kelayakan isi, kelayakan penyajian, kelayakan bahasa menurut BSNP dan penilaian kontekstual diperoleh 93,75\% termasuk dalam rentang persentase 86\%-100\%, kategori "Sangat Layak" dengan keputusan produk siap dipakai di lapangan tanpa revisi. Selanjutnya hasil validasi oleh ahli media terhadap bahan ajar terkait aspek kelayakan kegrafikan menurut BSNP terdiri dari ukuran buku ajar, desain sampul buku ajar, dan desain isi buku ajar diperoleh $88 \%$ termasuk dalam rentang persentase 86\%-100\%, kategori "Sangat Layak" dengan keputusan produk siap dipakai di lapangan tanpa revisi.

Ketiga, tingkat efektivitas bahan ajar diperoleh dari lembar observasi respons guru dan siswa terhadap bahan ajar, serta hasil tes menulis cerpen siswa. Adapun hasil penilaian observer dapat diketahui bahwa lembar observasi aktivitas guru dan siswa menggunakan pendekatan kontekstual diperoleh nilai 3,65. Apabila dilihat dari tabel kriteria penilaian aktivitas guru dari Mulyana (2018) maka nilai 3,65 termasuk dalam rentang $3,51 \leq$ nilai $\leq 4,00$ sehingga termasuk dalam kategori "Sangat Baik". Berdasarkan hasil perhitungan diketahui bahwa respons guru terhadap bahan ajar diperoleh persentase sebesar 96,73\%. Apabila dilihat dari tabel uji kelayakan produk maka 96,73\% termasuk dalam persentase 86\%-100\%, kategori "Sangat Layak" dengan keputusan produk siap dipakai di lapangan tanpa revisi. Selanjutnya hasil perhitungan respons siswa terhadap bahan ajar maka diperoleh rata-rata persentase adalah $88,94 \%$ termasuk dalam rentang persentase $86 \%-100 \%$, kategori "Sangat Layak" dengan keputusan produk siap dipakai di lapangan tanpa revisi.

Secara umum, hasil tes menulis cerpen menghasilkan nilai rata-rata 85,9 termasuk dalam kategori sangat baik. Dari 30 siswa terdapat 56,66\% atau 17 siswa yang memiliki hasil tes menulis cerpen dengan kategori sangat baik dalam rentang 85-100. Kategori baik dengan rentang 75-84 terdapat 43,33\% atau 13 siswa. Hasil tes menulis cerpen pada aspek latar (100\%), tema (97,5\%) dan penggunaan bahasa $(90,83 \%)$ termasuk dalam kategori sangat baik.

\section{DAFTAR PUSTAKA}

Aksan, H. (2011). Proses Kreatif Menulis Cerpen. Bandung: Nuansa.

Dalman. (2018). Keterampilan Menulis. Depok: Rajawali Press.

Devi, R. A., \& Hidayati, R. (2016). Penerapan Strategi Pembelajaran Kontekstual

Berbasis Kearifan Lokal Pada Mata Pelajaran IPS Di SDN Duduklor Kecamatan Glagah Kabupaten Lamongan. Seminar Nasional Pendidikan 2016 'Pengembangan Pendidikan Karakter Bangsa Berbasis Kearifan Lokal Dalam Era MEA', 106-111. Jember. Retrieved from https://jurnal.unej.ac.id/index.php/fkip-epro/article/view/5853

Gall, M. D., Gall, J. P., \& Borg, W. R. (2003). Educational Research: An Introduction (7th ed.). London: Longman.

Harefa, A. (2007). Mengukir Kata, Menata Kalimat. Yogyakarta: Gradien Books.

Majid, A. (2007). Perencanaan Pembelajaran Mengembangkan Standar Kompetensi Guru. Bandung: PT. Remaja Rosdakarya.

Murray, R., \& Moore, S. (2009). The Handbook of Academic Writing: A Fresh Approach.

New York: McGraw-Hill. 
Nurhana, Siddik, M., \& Ridhani, A. (2020). Pengembangan Bahan Ajar Menulis Cerpen dengan Teknik Parafrase pada Peserta Didik Kelas XI MAN 2 Samarinda. Diglosia: Jurnal Kajian Bahasa, Sastra, Dan Pengajarannya, 3(2), 211220. https://doi.org/10.30872/diglosia.v3i2.63

Padmi, J. (2017). Peningkatan Kemampuan Menulis Cerita Pendek Melalui Pendekatan Kontekstual pada Siswa SMP Kelas VII. Jurnal Pendidikan (Teori Dan Praktik), 2(1), 31-38. https://doi.org/10.26740/jp.v2n1.p31-38

Prastowo, A. (2013). Panduan Kreatif Membuat Bahan Ajar Inovatif. Yogyakarta: Diva Press.

Purwanto. (2010). Evaluasi Hasil Belajar. Yogyakarta: Pustaka Pelajar.

Rajja, Arifin, M. B., \& Mursalim. (2020). Pengembangan Bahan Ajar Menulis Teks Cerpen dengan Metode Cerpen-gram untuk Siswa Kelas IX di Kecamatan Muara Wahau. Diglosia: Jurnal Kajian Bahasa, Sastra, Dan Pengajarannya, 3(1), 24-32. https://doi.org/10.30872/diglosia.v3i1.26

Ramdani, E. (2018). Model Pembelajaran Kontekstual Berbasis Kearifan Lokal sebagai Penguatan Pendidikan Karakter. JUPIIS: Jurnal Pendidikan Ilmu-Ilmu Sosial, 10(1), 1-10. https://doi.org/10.24114/jupiis.v10i1.8264

Sanjaya, W. (2012). Strategi Pembelajaran Berorientasi Standar Proses Pendidikan. Jakarta: Kencana.

Sugiyono. (2016). Metodologi Penelitian Kuantitatif, Kualitatif, dan R\&D. Bandung: Alfabeta.

Umami, L. R. (2018). Pengembangan LKPD Menulis Puisi Berbasis Pendekatan Kontekstual Untuk Siswa SMP Kelas VIII (Universitas Lampung). Universitas Lampung. Retrieved from http://digilib.unila.ac.id/31433/

Wafiqni, N., \& Nurani, S. (2019). Model Pembelajaran Tematik Berbasis Kearifan Lokal. Al-Bidayah: Jurnal Pendidikan Dasar Islam, 10(2), 255-270. https://doi.org/10.14421/al-bidayah.v10i2.170

Wijayanti, W., Zulaeha, I., \& Rustono. (2015). Pengembangan Bahan Ajar Interaktif Kompetensi Memproduksi Teks Prosedur Kompleks yang Bermuatan Kesantunan bagi Peserta Didik Kelas X SMA/MA. Seloka: Jurnal Pendidikan Bahasa Dan Sastra Indonesia, 4(2), 94-101. Retrieved from https://journal.unnes.ac.id/sju/index.php/seloka/article/view/9866/6306

Yamin, M. (2013). Strategi dan Metode dalam Model Pembelajaran. Jakarta: Referensi (GP Press Group). 